\title{
Analysis cluster of palm processing industry in Indonesia
}

\author{
Erfit; Yulmardi \\ Faculty of Economics and Business, University of Jambi, Indonesia \\ e-mail correspondence: erfitibrahim@yahoo.com
}

\begin{abstract}
The purposes of this research are: 1) to analyze profile of palm processing cluster from upstream up to downstream in various regions in Indonesia; 2) to analyze strength, weakness, threats, and opportunity in palm processing industry, moreover to identify the role of existing various institutions in palm processing industry cluster in steering palm processing industry development; 3 ) to formulate the policy of palm processing cluster to encourage agricultural development. Data used in this research is secondary data that obtained from related institutions. Data is analyzed descriptively and quantitatively, utilizing frequency of distribution's table, crosstable, and SWOT analysis. The result of this research concludes that Indonesia has big potential to palm processing industry, particularly in upstream industry. This thing can be seen from wide of area and palm production, which are owned. From the region side, majority wide of the area and palm production in Sumatera, from wide of area's viewpoint is approximately $63.26 \%$ in Sumatera region, from production's viewpoint is approximately $68.71 \%$. In the meantime, from the downstream product, palm-processing industry in Indonesia is still limited. Less or more 100 products derived from palm in Indonesia, are only able producing 23 kinds of derived products, meanwhile in Malaysia almost reaching out 70 varieties.
\end{abstract}

Keywords: Palm processing industry, cluster, SWOT analysis

\section{INTRODUCTION}

Until this time palm is still one of plantation crops, which is notable for national economy, especially as income source, availability of job vacancy, and contributing foreign exchange. In some regions in Indonesia, palm constitutes one of main activities that expected as stimulus of economy of those regions. This condition cannot be separated from the ability of Indonesia, from the availability of landside, as well as agro-climatology that will enable constantly evolved of palm (Ministry of Economy, 2011).

To encourage the development of palm from upstream up to the downstream, then the government builds palm processing industry cluster in both Sumatera and Kalimantan. Of the four industries built, three of them are in Sungai Mangkei Sumatera Utara, Dumai, and Kuala Enok Riau.

As a cluster, need to group of enterprises from upstream up to downstream which is related each other so require collaboration or partnership among of the enterprises in a cluster. However, many researches to industry cluster can be concluded there is still weak cooperation or partnership from the existing of various parts in the cluster (Djamhari, 2006 and Nugroho, 2008). Utilizing assumption as stated in Tona et al (2013) concludes that the partnership among of enterprises group in palm processing industry cluster has not effective yet, ranging from upstream up to downstream in Jambi 
Province. On the other hand, there are some empirical researches show most of the partnership in plantation field, especially in upstream parties from palm industry processing cluster have not given optimally yield (Erfit, 1992, Silitonga 1995, Basdabella, 2001 Hasbi, 2001 and Erfit, 2012). The partnership results have not still optimally yet, it caused by the partnership all the time is more seen as economic relationship only, and negate the partnership as social relationship (Erfit, 2010).

As described above, this research aimed at to analyze profile of palm processing industry in various Indonesia region and palm processing industry's development policy to encourage agricultural development.

\section{RESEARCH METHOD}

Data used in this research is secondary data that obtained from related institutions, viz. Statistic Bureau, National Institution of Planning and Development, Region Institution of Planning and Development, and others. The periods comprise five years 2010-2014. The collected data covers development of palm processing industry cluster ranging from upstream up to the downstream. In additionally, the collected data also has existing associated policy in development of palm processing industry.

Data is analyzed descriptively and quantitatively, utilizing frequency of distribution's table, crosstable, and SWOT analysis. These methods aimed at formulating effective a partnership model, so that the qualitative research methods are considered more appropriate.

\section{RESULT AND DISCUSSION}

\section{Profile of Indonesian palm processing industry cluster}

According to rule of Industry Minister of Indonesia Number.13/2010 regarding road map the development of palm processing industry cluster, industry cluster of processing palm covers upstream/raw material, primary production industry, downstream industry, and related industry and supporting industry.

The development of palm processing industry in Indonesia cannot be separated from development plantation area and palm production constitute raw materials source from palm processing industry. Of palm plantation can produces fruit palm, in the form of TBS (fresh fruit bunches) constitute upstream industry from palm processing industry. TBS can be proceeding into raw palm oil or CPO and PKO constitute part of downstream industry from palm.

In general, processed product from that palm can de differentiated into two groups, such as oleo food and oleo chemical. In oleo food from palm can be produced into oil, margarine, and shortening. In the meantime, to oleo chemical from palm can be produced into soap, cosmetics, washing powder (detergent), and skyer.

The development of palm processing industry cannot be separated from the development of wide of area, production, and palm productivity in Indonesia ranging from 2010-2014, as follows (Table.1)

Table 1. Wide of area, production dan productivity palm plantation in Indonesia 2010 - 2014

\begin{tabular}{cccc}
\hline Year & Wide of Area (Ha) & Production (Ton) & Productivity (Kg/Ha) \\
\hline 2010 & 8.385 .394 & 21.958 .120 & 3.595 \\
2011 & 8.992 .824 & 23.096 .541 & 3.526 \\
2012 & 9.572 .715 & 26.015 .518 & 3.722 \\
2013 & 10.465 .020 & 27.782 .004 & 3.536 \\
2014 & 10.956 .231 & 29.344 .479 & 3.568 \\
\hline
\end{tabular}

Source: Agricultural Statistic (2014) 
In 2010 the total area of oil palm plantations in Indonesia was 8,385,394 ha and this area increased to $10,956,231$ ha in 2014. The same condition also at the level of palm oil production also increased. Production of oil palm plantations amounted to $21,958,120$ tons and in 2014 increased to $29,344,479$ tons. This condition has made Indonesia since 2010 as the largest palm oil producer in the world previously held by Malaysia. Thus in upstream part of the state of Indonesia has considerable potential for the palm oil processing industry.

If viewed from the aspect of location or its distribution based on the region in Indonesia, seen most of the area and production of oil palm plantations are in the region of Sumatra. In 2014 about 63.26 percent of oil palm plantation area in Indonesia is in Sumatra region and from production side about 68.71 percent of palm oil plantation production come from Sumatera region. Next followed by the territory of Kalimantan, Sulawesi, Papua and Maluku as well as Bali region (Table 2)

Table 2. Wide of area, palm production in Indonesia regarding region 2014

\begin{tabular}{|c|c|c|}
\hline Province & Wide of Area (Ha) & Production (Ton) \\
\hline Aceh & 420.173 & 945.617 \\
\hline Sumatera Utara & 1.396 .273 & 4.870 .202 \\
\hline Sumatera Barat & 435.792 & 924.813 \\
\hline Riau & 3.021 .559 & 6.993 .241 \\
\hline Kepualauan Riau & 43.892 & 45.001 \\
\hline Jambi & 711.919 & 1.773 .735 \\
\hline Sumatera Selatan & 1.518 .981 & 2.791 .816 \\
\hline Kepulauan Bangka Belitung & 416.005 & 516.597 \\
\hline Bengkulu & 319.222 & 798.818 \\
\hline Lampung & 208.068 & 455.904 \\
\hline SUMATERA REGION & 6.803.547 & 20.115 .744 \\
\hline DKI & - & - \\
\hline Jawa Barat & 13.624 & 33.020 \\
\hline Banten & 19.724 & 24.300 \\
\hline Jawa Tengah & - & - \\
\hline D.I. Yogyakarta & - & - \\
\hline Jawa Timur & - & - \\
\hline JAVA REGION & 33.348 & $\mathbf{5 7 . 3 2 0}$ \\
\hline Bali & - & - \\
\hline Nusa Tenggara Barat & - & - \\
\hline Nusa Tenggara Timur & - & - \\
\hline NUSA TENGGARA AND BALI & - & - \\
\hline Kalimantan Barat & 936.407 & 1.965 .515 \\
\hline Kalimantan Tengah & 1.115 .933 & 3.158 .239 \\
\hline Kalimantan Selatan & 512.897 & 1.460 .566 \\
\hline Kalimantan Timur & 733.397 & 1.407 .337 \\
\hline Kalimantan Utara & 153.315 & 255.703 \\
\hline KALIMANTAN REGION & 3.451 .949 & 8.247 .361 \\
\hline Sulawesi Utara & & - \\
\hline Gorontalo & 4.306 & - \\
\hline Sulawesi Tengah & 147.912 & 254.363 \\
\hline Sulawesi Selatan & 50.914 & 78.893 \\
\hline Sulawesi Barat & 106.365 & 285.523 \\
\hline Sulawesi Tenggara & 45.206 & 70.974 \\
\hline SULAWESI REGION & 354.704 & 689.752 \\
\hline Maluku & 10.297 & - \\
\hline Maluku Utara & - & - \\
\hline Papua & 51.360 & 94.022 \\
\hline Papua Barat & 49.597 & 73.991 \\
\hline MALUKU AND PAPUA & 111.254 & 168.013 \\
\hline Indonesia & 10.754 .801 & 29.278 .189 \\
\hline
\end{tabular}


Furthermore, based on the palm processing industry, ranging from fresh fruit bunches (FFB) produced by oil palm plantations processed into palm oil (CPO) and palm kernel ((PKO) through palm oil mills (PKS).) Judging from the production of CPO and PKO Indonesia are also increasing from year to year. In 2010, Indonesian CPO production reached $21,958,120$ tons and increased to $29,278,189$ tons in 2014 , while for PKO in 2010 the amount of Indonesian production amounted to 4,391,624 tons and increased to 5,855,638 tons in 2014 (Table 3).

Table 3. Palm oil production (CPO) dan palm kernel (PKO) in Indonesia 2010 - 2014 (in ton)

\begin{tabular}{ccc}
\hline Year & Palm Oil (CPO) & Palm Kernel (PKO) \\
\hline 2010 & 21.958 .120 & 4.391 .624 \\
2011 & 23.096 .541 & 4.619 .308 \\
2012 & 26.015 .518 & 5.203 .104 \\
2013 & 27.782 .004 & 5.556 .401 \\
2014 & 29.278 .189 & 5.855 .638 \\
\hline
\end{tabular}

Source: Plantation statistics 2014 - 2016

Furthermore, if seen downstream industry from the palm oil processing industry that can be produced by Indonesia is still very limited. For example, over 100 different types of derivative products from Indonesian palm oil processing can only produce 23 types of derivative products / downstream of palm oil such as cooking oil, margarine and some other food products, while Malaysia is able to produce 70 derivative products from palm (Affifudin, 2007). Then if viewed from the diversification of its products then about 90 percent of downstream products of palm oil are food products such as cooking oil and margarine while only 10 percent of which are non-food products such as soap, candles and others.

If studied further Indonesia has a great opportunity for the development of downstream industries of palm oil are not only for food products but also non-food products or oleo chemical industries whose market opportunities are still wide open. What's more, Indonesia still has a huge potential in terms of availability of large land and the availability of labor for palm oil plantation processing which is the basic capital for the development of palm oil processing industry. In fact, however, the CPO importing countries from Indonesia are in fact oleo chemical industries far more developed and developed than Indonesia and even more they have been able to produce more downstream CPO-based products with higher added value and will sell them to various countries including Indonesia with a more expensive price.

This condition is clearly detrimental to Indonesia because most of the value added of palm processing industry is more enjoyed by other countries. Therefore, it is necessary to develop various policies to develop the palm oil processing industry from the upstream industry or raw material source to the downstream industry, so that the huge potential of Indonesia's palm oil can provide the greatest benefit to push economic growth, which in turn will be able to improve people's welfare.

\section{SWOT analysis to indonesian palm processing industry}

In order to develop the palm oil processing industry in Indonesia it is necessary to note the strengths, weaknesses, opportunities and threats to the palm processing industry itself. SWOT analysis is used as a basis in the development of palm oil processing industry in Indonesia in the future. Table 4 provides a SWOT analysis of the palm processing industry for Indonesia. 
Table 4. SWOT analysis to palm processing industry in Indonesia

\begin{tabular}{|c|c|}
\hline Strength & Weakness \\
\hline $\begin{array}{l}\text { - Indonesia is the largest producer of palm in the } \\
\text { world and almost } 70 \text { percent of the national TBS } \\
\text { plantation production comes from Sumatra } \\
\text { (Plantation statistics, 2014). } \\
\text { - The condition of Indonesian agroclimates is } \\
\text { suitable for plantation crop especially palm. } \\
\text { - The availability of land for palm crops in } \\
\text { Indonesia, especially in the region of Sumatra } \\
\text { and Kalimantan. } \\
\text { - There is government support for palm } \\
\text { development especially for Sumatra region. With } \\
\text { the Master plant of Acceleration and Expansion } \\
\text { of Indonesian Economic Development (MP3EI) } \\
\text { 2011-2025 based on Presidential Decree No. } 32 \\
\text { of } 2011 \text { which confirms that in Sumatra corridor } \\
\text { has been established that one of the products to } \\
\text { be developed is palm. } \\
\text { - Potential demand for palm is still large for both } \\
\text { the domestic market and export. } \\
\text { - Potential development of palm processing } \\
\text { - Hndustry is wide enough. } \\
\text { - Aas considerable potential both in terms of } \\
\text { of regional economic growth. } \\
\text { - As a source of labor supply }\end{array}$ & $\begin{array}{l}\text { - Infrastructure still limited that can encourage the } \\
\text { development of palm processing industry, espe- } \\
\text { cially ports, roads and other basic infrastructure. } \\
\text { - Most production is still in the form of crude } \\
\text { palm oil (CPO). Approximately } 70 \text { percent of } \\
\text { CPO exports are in the form of crude oil (CPO). } \\
\text { - There is still very limited product of } \\
\text { downstream palm industry that is generated so } \\
\text { that the great potential for palm oil has not yield } \\
\text { optimal results. Of the more than } 100 \text { species } \\
\text { that can be produced on an industrial scale, } \\
\text { however, only about } 23 \text { types of palm oil } \\
\text { products are both commercially viable and } \\
\text { commercially available in Indonesia, while } \\
\text { Malaysia has already reached } 73 \text { downstream } \\
\text { products (Ministry of Industry, } 2009 \text { ). } \\
\text { - The development of the palm oil industry has } \\
\text { generated various social conflicts within the } \\
\text { community mainly from land problems. } \\
\text { The development of the palm oil industry has } \\
\text { created environmental problems. The US } \\
\text { government issued a decision through its } \\
\text { notation that oil palm crude (CPO) from } \\
\text { Indonesia is not considered environmentally } \\
\text { friendly so it should not be traded in the US. } \\
\text { - Limited incentives for investors to invest in } \\
\text { mownstream palm industry. } \\
\text { enagement are still limited so that business } \\
\text { in the city of Jambi eg financial institutions and } \\
\text { research institutions. } \\
\text { and less effective. }\end{array}$ \\
\hline
\end{tabular}

\begin{tabular}{|c|c|}
\hline Opportunity & Threat \\
\hline $\begin{array}{l}\text { - The market opportunities are still wide open for } \\
\text { both crude palm oil and its derivative products. } \\
\text { - Potential development of downstream palm } \\
\text { industry large enough for both food and non- } \\
\text { food. } \\
\text { - There is a high public interest in the use of } \\
\text { renewable energy, one of which is sourced from } \\
\text { palm oil. } \\
\text { - Has a large enough market potential. }\end{array}$ & $\begin{array}{l}\text { - High palm oil price fluctuations and other palm } \\
\text { oil derivatives products. } \\
\text { - Only a negative campaign against palm oil. } \\
\text { - There is a negative impact of palm oil } \\
\text { development so far in both social conflicts and } \\
\text { environmental degradation. }\end{array}$ \\
\hline
\end{tabular}

\section{Institutionalization of palm processing industry in Indonesia}

The various institutions in the palm processing industry will affect the development of palm processing industry in Indonesia. The following will explain some 
existing institutions in the palm oil processing industry from the upstream industry to downstream industry.

\section{Farmers group}

In general, farmer groups are groups of farmers are formed by farmers based on equality of interests, equality of social environment conditions of economy and resources, commodity equality and intimacy to improve and develop business. One important factor that plays an important role in the development of palm oil processing industry is the existence of farmer groups, especially in the upstream industry. This is because the farmers' groups will be able to strengthen the bargaining position of the farmers rather than the farmers themselves. In addition, with the institutional, strengths and potentials of farmers can be gathered into a common strength and potency that has a stronger strength. Thus, the existence of strong farmer institution is much needed in encouraging the development of palm oil processing industry in the future. However, from some of the results of the existing farmer group research has not yet played a maximum role.

\section{APKASINDO}

Association of Indonesian Oil Palm Farmers (Apakasindo) is a professional organization of farmers as a unifying container of oil palm farmers in Indonesia. As an oil palm farming organization in accordance with its AD / RT, Apkasindo's objectives are: a) to unite the community of the coconut farmers into one of the economic forces that can improve the equitable welfare of the oil palm farmers; b) to build the rural economy by cultivating efforts of oil palm farmers who are environmentally friendly and beneficial to all components of the nation; c) improve and empower the human resources of oil palm farmers.

\section{GAPKI .}

The Indonesian palm business association (GAPKI) is an organization that brings together palm entrepreneurs. As a GAPKI organization works to discuss various problems faced by palm entrepreneurs and provide input to the problems faced. GAPKI members consist of various elements including state-owned plantation companies, private and foreign-owned. Then the palm farmers who joined a cooperative also became members of this GAPKI.

\section{The policy of palm processing industry in Indonesia}

The policies in the development of the palm oil processing industry can be seen in the form of laws, regulations, decisions and programs made especially in relation to the partnership and plantation programs in general. Below are some of the development programs of palm oil processing industry in Indonesia.

\section{Parternship Program}

The plantation development policy is generally regulated in Act No. 18 of 2004 on plantations, especially those described in Article 22, which regulate the partnership of business in the field of plantation. In article 22 of Act No. 18 of 2004 mentioned that the plantation company in running a mutually beneficial partnership, mutual respect, mutual responsibility, mutual strengthening and interdependence with the planters, employees and surrounding communities. The partnership pattern of plantation business can be in the form of cooperation of supply of production facilities, production cooperation, processing and marketing, transportation, operational cooperation, share ownership and other supporting services.

In the course of the partnership program has experienced various developments tailored to its needs or in order to encourage other development programs such as in 
support of the transmigration program. Among others are through partnership program of PIR plantation, PIR Trans and KPPA partnership model. The Trans PIR Partnership was built under Presidential Instruction No. 1 of 1986 explaining that the Trans PIR is a PIR project linked to the transmigration program. As with the PIR partnership model in general in this model the implementation of plantation development by using large plantations as the core of both state-owned and private companies that help and guide the surrounding community plantations as plasma in this case the transmigration through a system of mutually beneficial, intact and sustainable cooperation. While the KPPA partnership model is based on a joint decision between the Minister of Agriculture and the Minister of Cooperatives and Small Business Development No.73 / Kpts / KB.510 / 2/1998 and No. 01 / SKB / M / 11/98. In KPPA partnerships are implemented through the provision of funding facilities provided by the government in the form of credit to primary cooperatives in this case KUD for its members are intended to increase non-oil production, increase farmer income, assist the development of the region and support the development of plantations, increase and empower KUD in the region plasma. In this case, the main thing is that large companies of plantations and plasma are members of the cooperative. The following table 5 can be comprehensively seen in various matters relating to partnership in the palm oil processing industry especially in the upstream section.

Table 5. The form of correlation and regulation in partnership based on the pattern of plantation's partnership

\begin{tabular}{|c|c|c|c|c|c|}
\hline \multirow[b]{2}{*}{ No } & \multirow{2}{*}{$\begin{array}{l}\text { Partnership } \\
\text { Patterns }\end{array}$} & \multicolumn{3}{|c|}{ Partnership Relations } & \multirow{2}{*}{$\begin{array}{c}\text { Forms of } \\
\text { Rules }\end{array}$} \\
\hline & & Capital & Marketing & Coaching & \\
\hline 1. & PIR Trans & $\begin{array}{l}\text { There are (given in } \\
\text { the form of credit } \\
\text { packages in the form } \\
\text { of business land as } \\
\text { transmigrants /plasma } \\
\text { gardens of } 2 \text { ha, } \\
\text { development of } \\
\text { gardens, seedlings, } \\
\text { fertilizers and } \\
\text { pesticides which is a } \\
\text { debt to smallholders) }\end{array}$ & $\begin{array}{l}\text { There (in the } \\
\text { form of a core } \\
\text { company is } \\
\text { obliged to buy } \\
\text { the production } \\
\text { produced by the } \\
\text { plasma farmer) }\end{array}$ & $\begin{array}{l}\text { There is (in the form } \\
\text { where the core } \\
\text { company provides } \\
\text { technical assistance in } \\
\text { the form of extension to } \\
\text { farmers related to } \\
\text { technical cultivation } \\
\text { and maintenance of the } \\
\text { garden) }\end{array}$ & $\begin{array}{l}\text { Formal in } \\
\text { the form of } \\
\text { a written } \\
\text { contract in } \\
\text { the form of } \\
\text { a letter of } \\
\text { cooperation } \\
\text { agreement } \\
\text { (SPK) }\end{array}$ \\
\hline 2. & KPPA & $\begin{array}{l}\text { There are (given in } \\
\text { the form of credit } \\
\text { packages in the form } \\
\text { of development of } \\
\text { gardens (land pre- } \\
\text { pared by smallhold- } \\
\text { ers), seedlings, fertili- } \\
\text { zers and pesticides } \\
\text { which are payable to } \\
\text { smallholders) }\end{array}$ & $\begin{array}{l}\text { There (in the } \\
\text { form of a partner } \\
\text { company is } \\
\text { obliged to buy } \\
\text { the produce } \\
\text { produced by the } \\
\text { plasma farmer) }\end{array}$ & $\begin{array}{l}\text { There is (in the form } \\
\text { where the core } \\
\text { company provides } \\
\text { technical assistance in } \\
\text { the form of extension to } \\
\text { farmers related to } \\
\text { technical cultivation } \\
\text { and maintenance of the } \\
\text { garden) }\end{array}$ & $\begin{array}{l}\text { Formal in } \\
\text { the form of } \\
\text { a written } \\
\text { contract in } \\
\text { the form of } \\
\text { a letter of } \\
\text { cooperation } \\
\text { agreement } \\
(\mathrm{SPK}))\end{array}$ \\
\hline 3. & $\begin{array}{l}\text { PIR } \\
\text { Plantation } \\
\text { Revitalization }\end{array}$ & $\begin{array}{l}\text { There are (given in } \\
\text { the form of credit } \\
\text { packages in the form } \\
\text { of development of } \\
\text { gardens (land pre- } \\
\text { pared by smallhold- } \\
\text { ers, seedlings, fertili- } \\
\text { zers and pesticides } \\
\text { that are payable to } \\
\text { smallholders) }\end{array}$ & $\begin{array}{l}\text { There (in the } \\
\text { form of a partner } \\
\text { company is } \\
\text { obliged to buy } \\
\text { the produce } \\
\text { produced by the } \\
\text { plasma farmer) }\end{array}$ & $\begin{array}{l}\text { There is (in the form } \\
\text { where the core } \\
\text { company provides } \\
\text { technical assistance in } \\
\text { the form of extension to } \\
\text { farmers related to } \\
\text { technical cultivation } \\
\text { and maintenance of the } \\
\text { garden) }\end{array}$ & $\begin{array}{l}\text { Formal in } \\
\text { the form of } \\
\text { a written } \\
\text { contract in } \\
\text { the form of } \\
\text { a letter of } \\
\text { cooperation } \\
\text { agreement } \\
\text { (SPK) }\end{array}$ \\
\hline
\end{tabular}




\section{Plantation revitalitation program}

Plantation Revitalization Program This revitalization program was built based on Minister of Agriculture Regulation No. 33/2006 and Minister of Finance Regulation No. 117/2006. The plantation revitalization program is an effort to accelerate people plantation development through expansion, rejuvenation and rehabilitation of plantation crops supported by investment banking credit and interest subsidy by the government with involving companies in the field of plantation business as development partners in the development of gardens, processing and marketing results. The selection of commodities to be developed is based on sources of community income, market prospects and employment and environmental factors. The objectives of this plantation revitalization program are to: a) increase employment opportunities and increase people's income through plantation development; b) enhance competitiveness through increased productivity and development of downstream plantation-based industries; c) increase national economic empowerment by involving communities and local entrepreneurs and d) support regional development. In order to achieve the objectives of the plantation revitalization program, one of them is through a partnership program called the partnership pattern of Plantation Revitalization PIR. PIR Plantation Revitalization is a pattern of cooperation between farmers participating in the plantation revitalization program with business partners who manage the garden in one management system for at least one planting cycle. In this case, the partner company develops the plasma farmers 'garden where the land comes from the community land or the farmers' property. Therefore, the community as landowners gives their land to the company to be plantation land. The development of plasma plantations is done by utilizing the credit facilities provided by the banks for the participants of the revitalization program usually through the KUD so that the program participants are members of the KUD. In addition to building farmers 'gardens, the partner companies are also obliged to provide technical assistance through farmers' gardening. Meanwhile, the farmer is obliged to sell his farm produce to the partner company

\section{MP3EI program}

MP3EI Program is the Master Plan for the Acceleration and Expansion of Indonesian Economic Development. With the MP3EI Indonesia is expected to accelerate the existing development of adding value to the sectors of the economy, infrastructure and energy development and human resources and science and technology development. Especially for superior products in the field of plantation, then in order to increase the role of commodities in MP3EI program established 3 investment economic corridors namely economic corridor Sumatra (oil palm and rubber), Kalimantan economic corridor (oil palm and rubber) and economic corridor Sulawesi (cocoa). Some special plantation development programs for palm oil processing industry include: a. Improved process through rejuvenation, rehabilitation and intensification using sufficient agro input and using certified superior seeds; b. Provision of technology packages with monoculture, diversification and integration of livestock; c. Support efficient and effective transportation through repairs, gardens roads, access roads, roads to factories, harbor roads; d.Improved increase in domestic through the development of agro-based commodity-based plantations; e.Expansion of batik, traditional market, supermarket etc.; f. The demand for sustainable development of a heap. 


\section{CONCLUSIONS AND RECOMMENDATIONS}

\section{Conclusions}

Indonesia has a considerable potential for palm processing industry especially in the upstream industry, this can be seen from the width of the area and production of palm plantations owned. Viewed from the side of the region most of the areas and oil palm production are located in Sumatra, where the area of oil palm is about 63.26 percent in Sumatra and 68.71 percent of Indonesia's palm oil production is in Sumatra region. Downstream products from the palm oil processing industry in Indonesia are still limited, from 100 new Indonesian palm oil derivatives products capable of producing 23 types of derivative products, while Malaysia can produce about 70 derived products. Indonesia has the opportunity and strength in the development of palm oil processing industry, but it also has obstacles and challenges. Some institutions that can encourage the development of palm oil processing industry in Indonesia include farmers groups, GAPKI and APKASINDO. Policies on oil palm processing industry development include partnership program, plantation revitalization and MP3EI program

\section{Recommendations}

Suggestion in the development of the palm oil processing industry still needs to be improved especially in the downstream industry. This can be done by providing incentives to the downstream palm oil processing industry to encourage investors to invest in the palm oil industry especially downstream.

\section{REFERENCES}

Afifuddin, S. (2007). Analisis determinan produksi industri minyak goren kelapa sawit provinsi Sumatera Utara. Jurnal Wawasan, Juni Volume 13 nomor 1. Medan.

Departemen Pertanian. 2014. Statistik Pertanian. Departemen Petanian. Jakarta.

Dirjen Perkebunan. 2014. Statistik Perkebunan. Dirjen Perkebunan Jakara.

Departemen Perindustrian. 2009. Peta panduan pengembangan klaster industri prioritas industri berbasis agro tahun 2010 - 2014. Jakarta.

Djamhari C. (2006). Faktor-faktor yang mempengaruhi perkembangan sentra UKM menjadi klaster dinamis. Infokop nomor 29 tahun XII. Jakarta.

Erfit. (2004). Analisis keberhasilan ekonomi dan distribusi pendapatan petani peserta PIR setelah masa konversi (Studi Kasus PIR-SUS II kelapa sawit Sungai Bahar kabupaten Muaro Jambi. Jurnal Manajemen dan Pembangunan Vol 3 No 1 Universitas Jambi. Jambi.

Erfit, Yulmardi. (2010). Rekonstruksi model kemitraan pada agribisnis hortikultura dalam upaya pengembangan wilayah sentra hortikultura: Studi kasus pada beberapa wilayah sentra hortikultura di Sumatera (Tahun II). Jambi.

Erfit. (2010). Pengembangan pola kemitraan pada agribisnis hortikultura. Disertasi Program Pascasarjana Universitas Andalas. Padang.

Erfit, Yulmardi. (2012). Model Kemitraan dengan Perspektif Ekonomi Kelembagaan di bidang Perkebunan dalam Mendorong Pembangunan Perkebunan Rakyat di Propinsi Jambi.

Endraswana, S. (2003). Metodologi penelitian kebudayaan. Gajah Mada University Press. Yokyakarta.

Hanani, N. 2004. Menggugat pembangunan indonesia yang tidak memberdayakan pembangunan pertanian. Majalah Agro-Ekonomika No 22. Jakarta.

Jatileksono, T. (1995). Peran agribisnis dalam proses pembangunan pertanian. Majalah Pangan VI. 24 : hal. 14-17. Jakarta. 
Kementerian Koordinator Bidang Perekonomian. 2011. Masterplan percepatan dan perluasan pembangunan ekonomi Indonesia 2011 - 2025. Jakarta.

Komisi Pengawasan Persaingan Usaha RI. Evaluasi kebijakan perkebunan kelapa sawit. Jakarta.

Kolopaking, L M. (2002). Pola-pola kemitraan dalam pengembangan usaha ekonomi lemah. IPB. Bogor.

Limbong, L. (1990). Analisa masalah konversi dan pengaruhnya terhadap tingkat pendapatan petani kelapa sawit peserta PIR-NES V Banten Selatan. Tesis Program Pascasarjana IPB. Bogor.

Strauss, A dan Corbin, J. (2005). Dasar-dasar penelitian kualitatif. Pustaka Pelajar. Jakarta.

Tona A L, Erfit, Yulmardi. (2012). Pengembangan Model Kemitraan Pada Industri Pengolahan Kelapa Sawit Dalam Perspektif Klaster Industri untuk Mendorong Pembangunan Wilayah Provinsi Jambi (Tahun I)

Tona A L, Erfit, Yulmardi. (2013). Pengembangan Model Kemitraan Pada Industri Pengolahan Kelapa Sawit Dalam Perspektif Klaster Industri untuk Mendorong Pembangunan Wilayah Provinsi Jambi (Tahun II) 